\title{
QUALITY ASSESSMENT, SPECIFICS OF ORGANIZATION AND PROVISION OF MEDICAL CARE TO STROKE PATIENTS ACCORDING TO THE HOSPITAL REGISTER OF VRCPH NAMED AFTER ACADEMICIAN O. I. YUSHCHENKO OF VRC AND VCCH EMS FOR THE PERIOD 2017-2019
}

\author{
Moskovko Serhiy Petrovych, \\ professor, National Pirogov Memorial Medical University, Vinnytsia, Ukraine
}

Fiks Dmytro Oleksandrovych, postgraduate, National Pirogov Memorial Medical University, Vinnytsia, Ukraine

Shayuk Alla Volodymyrivna, docent, Zhytomyr Ivan Franko State University, Zhytomyr, Ukraine

Cherkasova Lyubov Anatoliyivna, docent, Bogomolets National Medical University, Kyiv, Ukraine

DOI: https://doi.org/10.31435/rsglobal_ws/30062020/7110

\section{ARTICLE INFO}

Received: 20 April 2020

Accepted: 12 June 2020

Published: 30 June 2020

\section{KEYWORDS}

stroke,

stroke treatment,

door-to-needle time,

duration of treatment,

stroke block,

register method.

\begin{abstract}
Currently, one of the most important tasks is to improve the quality of medical services, which becomes possible in retrospective register analysis of medical and organizational technologies, which include algorithms for providing medical care, continuity of medical institutions, protocols for diagnosis and treatment of diseases. The stroke register was created on the basis of medical documentation of hospitals, which are the most typical for the Podillia region of Ukraine. Statistical processing of the results was performed using the licensed statistical package "Statistica 5.5" using parametric evaluation methods. Significant differences in the organization of the medicaldiagnostic process and approaches to treatment have been established between the two medical institutions of Vinnytsia in the dynamics of time. There was a positive trend in the time of stroke treatment, the use of drugs with a high degree of evidence and the coverage of patients with specialized, multidisciplinary care in a stroke.
\end{abstract}

Citation: Moskovko S. P., Fiks D. O., Shayuk A. V., Cherkasova L. A. (2020) Quality Assessment, Specifics of Organization and Provision of Medical Care to Stroke Patients According to the Hospital Register of VRCPH Named After Academician O. I. Yushchenko of VRC and VCCH EMS for the Period 2017-2019. World Science. 6(58), Vol.2. doi: 10.31435/rsglobal_ws/30062020/7110

Copyright: (C) 2020 Moskovko S. P., Fiks D. O., Shayuk A. V., Cherkasova L. A. This is an openaccess article distributed under the terms of the Creative Commons Attribution License (CC BY). The use, distribution or reproduction in other forums is permitted, provided the original author(s) or licensor are credited and that the original publication in this journal is cited, in accordance with accepted academic practice. No use, distribution or reproduction is permitted which does not comply with these terms.

Introduction. At present, there is no suitable alternative for the treatment of patients with acute cerebrovascular accident (ACA) in specialized stroke departments and centers. The experience of different countries shows that adequate, timely care for patients at the inpatient stage can be provided only in specialized centers, departments or units (stroke unit) [1]. The center includes a broader concept compared to the department: in the center, the treatment and diagnostic process begins immediately upon admission to the hospital, and therefore - with the assessment of the possibility of thrombolysis [2]. 
In Ukraine, there is a question of establishing stroke centers and departments in both large cities and regional centers to provide highly qualified, specialized care to patients with ACA with the involvement of multidisciplinary teams consisting of specially trained medical staff [3]. Early discharge with subsequent accompaniment (supervision) of the patient in the context of multidisciplinary team care shows good results in patients, significantly reduces the time spent in the stroke unit and in the hospital in general $[4,5]$. The establishment of these units in our country is the most effective strategy for providing care to patients with ACA. They are effective and cost-effective for the future, as they are more effective in reducing mortality and disability [6].

Treatment of the acute period of stroke includes basic therapy and prevention of somatic complications. Given the high mortality rate during the first month and the next 12 months after stroke, it is necessary to begin prevention of recurrent stroke in parallel with the provision of emergency specialized medical care to patients with ACA [7, 8]. The main principles of secondary prevention are the correction of risk factors and drug therapy. The strategy of individualized secondary stroke prevention is developed in the first day of the patient's stay in the hospital. It includes the use of statins, antihypertensive, antithrombotic drugs, correction of carbohydrate metabolism disorders, if necessary - surgical treatments $[9,10]$.

The purpose of the research - to study and compare the organization and level of medical care for stroke patients according to the registers of hospitals in Vinnytsia during 2017-2019.

Material and methods of research. Data on stroke cases were obtained on the basis of medical documentation of medical institutions that are most typical for the Podillia region of Ukraine (Vinnytsia, most of Khmelnytsky, part of Ternopil, as well as small adjacent areas of Zhytomyr and Cherkasy regions). Data collection and processing was performed by a certified neurologist.

We conducted a retrospective analysis of the results of medical histories of patients hospitalized for emergency appointments to the stroke unit of the Municipal Non-Profit Enterprise «Vinnytsia Regional Clinical Psychoneurological Hospital named after Academician O. I. Yushchenko of Vinnytsia Regional Council» (VRCPNH) or Vinnytsia City Clinical Hospital of Emergency Medical Services (VCCHEMS) for the period 2017-2019 with a diagnosis of ACA (Table 1). After inpatient treatment, a RES-Q report form was completed on a case-by-case basis - a special report form in an international program developed by the European Stroke Society (ESO) ESO-EAST initiative. Since 2017, the hospitals we surveyed have been participating in this program.

Table 1. Distribution of patients with ACA in VRCPNH or VCCHEMS stroke unit for 2017-2019.

\begin{tabular}{|l|l|l|c|c|c|}
\hline \multirow{3}{*}{$\begin{array}{l}\text { Groups } \\
\text { surveyed }\end{array}$} & \multirow{2}{*}{ Years of research } & \multicolumn{4}{|c|}{ Hospitals } \\
\cline { 3 - 6 } & & men & women & men & women \\
\cline { 3 - 6 } & 2017 & 307 & 209 & 351 & 335 \\
\hline \multirow{3}{*}{ General } & 2018 & 312 & 187 & 310 & 306 \\
\cline { 2 - 6 } & 10 months of 2019 & 287 & 175 & 182 & 163 \\
\hline \multirow{3}{*}{$\begin{array}{l}\text { Ischemic } \\
\text { stroke }\end{array}$} & 2017 & 269 & 184 & 308 & 296 \\
\cline { 2 - 6 } & 2018 & 267 & 166 & 276 & 282 \\
\cline { 2 - 6 } & 10 months of 2019 & 248 & 152 & 162 & 153 \\
\hline \multirow{3}{*}{$\begin{array}{l}\text { Hemorrhagic } \\
\text { stroke }\end{array}$} & 2017 & 37 & 25 & 42 & 39 \\
\cline { 2 - 6 } & 2018 & 45 & 21 & 20 & 24 \\
\cline { 2 - 6 } & 10 months of 2019 & 39 & 23 & 20 & 10 \\
\hline
\end{tabular}

Data on the treatment were recorded: the use of certain groups of drugs (antihypertensive, antithrombolytic, statins), recanalization intervention, hematoma surgery. The quality indicators of the organization of the medical-diagnostic process were also considered: door-to-needle time, duration of treatment, hospitalization to the stroke unit.

Statistical processing of the survey results was performed using the statistical package "Statistica 5.5" (licensed № AXXR910A374605FA) using parametric evaluation methods.

Results and discussion. When comparing the percentage of patients who were hospitalized for stroke, VRCPNH found a significantly $(\mathrm{p}<0.05-0.001)$ higher value in patients with ischemic stroke $(2017-76.9 \%$ in men in general and $74.7 \%$ with ischemic stroke; $70.3 \%$ in women in general and $69.0 \%$ with ischemic stroke; in $2018-97.8 \%$ in men in general, $97.4 \%$ with ischemic stroke and 
$100 \%$ with hemorrhagic stroke; $98.9 \%$ in women in general, $98.8 \%$ with ischemic stroke and $100 \%$ with hemorrhagic stroke; in $2019-97.2 \%$ in men in general and $97.2 \%$ with ischemic stroke; $98.3 \%$ in women in general and $98.7 \%$ with ischemic stroke) compared to VCCHEMS (2017 - 57.0\% in men in general and $52.9 \%$ with ischemic stroke; $58.5 \%$ in women in general and $56.4 \%$ with ischemic stroke; in $2018-74.5 \%$ in men in general, $72.5 \%$ with ischemic stroke and $91.5 \%$ with hemorrhagic stroke; $76.5 \%$ in women in general, $76.6 \%$ with ischemic stroke and $75.0 \%$ with hemorrhagic stroke; $2019-85.7 \%$ of men in general and $85.2 \%$ with ischemic stroke; $87.7 \%$ in women in general and $86.9 \%$ with ischemic stroke).

In VRCPNH, the percentage of patients who were hospitalized in the stroke unit in the dynamics of 2017-2019 significantly $(\mathrm{p}<0.05-0.001)$ increased $(2017-76.9 \%$ in men in general, $74.7 \%$ with ischemic stroke and $91.9 \%$ with hemorrhagic stroke; $70.3 \%$ in women in general, $69.0 \%$ with ischemic stroke and $80.0 \%$ with hemorrhagic stroke; in $2018-97.8 \%$ in men in general, $97.4 \%$ with ischemic stroke and $100 \%$ with hemorrhagic stroke; $98.9 \%$ in women in general, $98.8 \%$ with ischemic stroke and $100 \%$ with hemorrhagic stroke; in $2019-97.2 \%$ for men in general and $97.2 \%$ with ischemic stroke; $98.3 \%$ for women in general and $98.7 \%$ with ischemic stroke).

VCCHEMS also significantly increased over time $(\mathrm{p}<0.01-0.001)$ the percentage of patients hospitalized for stroke (2017 - 57.0\% in men in general, $52.9 \%$ in ischemic stroke; $58.5 \%$ in women in general, $56.4 \%$ in ischemic stroke; in $2018-74.5 \%$ in men in general, $72.5 \%$ with ischemic stroke; $76.5 \%$ in women in general, $76.6 \%$ with ischemic stroke; in $2019-85.7 \%$ in men in general and $85.2 \%$ with ischemic stroke; $87.7 \%$ in women in general and $86.9 \%$ with ischemic stroke).

There were no significant differences in the intake of vitamin $\mathrm{K}$ antagonist by patients between medical institutions and in the dynamics of time.

When comparing the percentage of patients receiving antiplatelet agents, VRCPNH in 20172019 found a significantly $(\mathrm{p}<0.05-0.001)$ lower value $(2017-68.7 \%$ in men in general, $77.3 \%$ with ischemic stroke; $66.5 \%$ in women in general, $75.0 \%$ with ischemic stroke; in $2018-69.9 \%$ in men in general, $81.3 \%$ with ischemic stroke; $66.8 \%$ in women in general, $74.7 \%$ with ischemic stroke; in $2019-61.7 \%$ in men in general and $71.4 \%$ in ischemic stroke; $53.7 \%$ in women in general and $60.5 \%$ in ischemic stroke) compared to VCCHEMS (2017 - 78.6\% in men in general, $85.7 \%$ in ischemic stroke; $77.0 \%$ in women in general, $84.5 \%$ with ischemic stroke; $2018-83.5 \%$ in men in general, $92.8 \%$ with ischemic stroke; $83.7 \%$ in women in general, $89.7 \%$ with ischemic stroke; in $2019-80.2 \%$ in men in general and $88.9 \%$ with ischemic stroke; $82.8 \%$ in women in general and $86.9 \%$ in ischemic stroke).

In VRCPNH, the percentage of patients receiving antiplatelet agents decreased significantly ( $\mathrm{p}<0.05-0.01)$ over time (2017 - 68.7\% in men in general, $77.3 \%$ in ischemic stroke; $66.5 \%$ in women in general, $75.0 \%$ with ischemic stroke; in $2018-69.9 \%$ in men in general, $81.3 \%$ with ischemic stroke; $66.8 \%$ in women in general, $74.7 \%$ with ischemic stroke; in $2019-61.7 \%$ in men in general and $71.4 \%$ with ischemic stroke; $53.7 \%$ in women in general and $60.5 \%$ with ischemic stroke).

In VCCHEMS, the percentage of patients receiving antiplatelet agents increased significantly over time ( $\mathrm{p}<0.05-0.01)$ (2017 - 78.6\% in men in general, $85.7 \%$ with ischemic stroke; $77.0 \%$ in women in general; in $2018-83.5 \%$ in men in general, $92.8 \%$ with ischemic stroke; $83.7 \%$ in women in general).

When comparing the percentage of patients receiving dabigatran, VRCPNH in 2017-2019 found a significantly $(\mathrm{p}<0.05-0.001)$ higher value $(2017-8.8 \%$ in men in general, $10.0 \%$ with ischemic stroke; $5.7 \%$ in women in general, $6.5 \%$ with ischemic stroke; in $2018-7.7 \%$ in men in general, $9.0 \%$ with ischemic stroke; $11.8 \%$ in women in general, $13.3 \%$ with ischemic stroke; in $2019-9.4 \%$ in men in general and $10.9 \%$ in ischemic stroke; $16.6 \%$ in women in general and $19.1 \%$ with ischemic stroke) compared to VCCHEMS (2017 - $0.9 \%$ in men in general, $1.0 \%$ with ischemic stroke' $0.6 \%$ in women in general, $0.7 \%$ with ischemic stroke' $2018-0.3 \%$ in men in general, $0.4 \%$ with ischemic stroke' $0.7 \%$ in women in general, $0.7 \%$ with ischemic stroke' in $2019-2.7 \%$ in men in general and $3.1 \%$ with ischemic stroke' $3.7 \%$ in women in general and $3.9 \%$ in ischemic stroke).

In VRCPNH, the percentage of patients receiving dabigatran increased significantly over time $(\mathrm{p}<0.05-0.01)(2017-8.8 \%$ in men in general, $10.0 \%$ in ischemic stroke; $5.7 \%$ in women in general, $6.5 \%$ with ischemic stroke; in $2018-7.7 \%$ in men in general, $9.0 \%$ with ischemic stroke; $11.8 \%$ in women in general, $13.3 \%$ with ischemic stroke; in $2019-9.4 \%$ in men in general and $10.9 \%$ with ischemic stroke; $16.6 \%$ in women in general and $19.1 \%$ with ischemic stroke). 
In VCCHEMS, the percentage of patients receiving dabigatran increased significantly ( $\mathrm{p}<0.05-0.01)$ over time $(2018-0.3 \%$ in men in general, $0.4 \%$ in ischemic stroke; $0.7 \%$ in women in general and $0.7 \%$ in ischemic stroke; $2019-2.7 \%$ for men in general, $3.1 \%$ with ischemic stroke; $3.7 \%$ for women in general and $3.9 \%$ with ischemic stroke).

When comparing the percentage of patients receiving rivaroxaban, VRCPNH in 2017 found a significantly $(\mathrm{p}<0.05)$ higher value $(2017-5.3 \%$ in women in general, $6.0 \%$ with ischemic stroke $)$ compared to VCCHEMS (2017 - $1.5 \%$ in women in general, $1.7 \%$ with ischemic stroke).

In VCCHEMS, the percentage of patients receiving rivaroxaban significantly increased over time ( $\mathrm{p}<0.05-0.01$ ) (in $2017-1.5 \%$ in women in general, $1.7 \%$ with ischemic stroke; in $2018-1.0 \%$ in men in general, $1.1 \%$ with ischemic stroke; $5.6 \%$ in women in general, $5.7 \%$ with ischemic stroke; in $2019-3.8 \%$ in men in general, $4.3 \%$ with ischemic stroke; $5.5 \%$ in women in general, $5.9 \%$ with ischemic stroke).

When comparing the percentage of patients receiving other antithrombotic drugs, VRCPNH in 2019 found a significantly higher value $(\mathrm{p}<0.01-0.001)(2019-4.5 \%$ in men in general, $5.2 \%$ with ischemic stroke; $6.3 \%$ in women in general, $7.2 \%$ with ischemic stroke) compared to VCCHEMS (2019 - 0\% for men in general, $0 \%$ with ischemic stroke; $0 \%$ for women in general, $0 \%$ with ischemic stroke).

In VRCPNH, the percentage of patients receiving other antithrombotic drugs in 2019 compared to 2017-2018 significantly $(\mathrm{p}<0.05-0.01)$ increased $(2017-0.4 \%$ in men with ischemic stroke; $1.4 \%$ in women in general, $0 \%$ with ischemic stroke; in $2018-0.6 \%$ in men in general, $0.4 \%$ with ischemic stroke; $0 \%$ in women in general, $0 \%$ with ischemic stroke; in $2019-5.2 \%$ in men with ischemic stroke; $6.3 \%$ in women in general, $7.2 \%$ with ischemic stroke).

When comparing the percentage of patients who did not receive any antithrombotic drug, VRCPNH found a significantly $(\mathrm{p}<0.05)$ higher value (in $2017-67.6 \%$ in men with hemorrhagic stroke; in $2019-11.4 \%$ in women in general, $2.6 \%$ with ischemic stroke) compared to VCCHEMS (2017 - 45.2\% in men with hemorrhagic stroke; in $2019-4.3 \%$ in women in general, $0 \%$ with ischemic stroke).

In VRCPNH, the percentage of patients who did not receive any antithrombotic drug in 2018 compared to 2017 and 2019 was significantly $(\mathrm{p}<0.05-0.01)$ higher $(2017-67.6 \%$ in men with hemorrhagic stroke; $60.0 \%$ in women with hemorrhagic stroke; in $2018-90.5 \%$ in women with hemorrhagic stroke; in $2019-94.9 \%$ in men with hemorrhagic stroke; $69.6 \%$ in women with hemorrhagic stroke).

In VCCHEMS, the percentage of patients who did not receive any antithrombotic drug in 2017 compared to 2018 and 2019 was significantly ( $<<0.05-0.01$ ) higher in patients with ischemic stroke and significantly $(\mathrm{p}<0.05-0.01)$ less - in patients with hemorrhagic stroke $(2017-45.2 \%$ in men with hemorrhagic stroke; $9.9 \%$ in women in general and $3.7 \%$ in ischemic stroke; in $2018-91.2 \%$ in men with hemorrhagic stroke; $6.2 \%$ in women in general and $0.7 \%$ in ischemic stroke; $2019-85.0 \%$ in men with hemorrhagic stroke; $4.3 \%$ in women in general and $0 \%$ with ischemic stroke).

When comparing the percentage of patients receiving statins, VRCPNH in 2017 found a significantly $(\mathrm{p}<0.01)$ higher, and in 2018 significantly $(\mathrm{p}<0.05)$ smaller its value in patients with ischemic stroke (2017 - 84.4\% in men in general and $92.9 \%$ with ischemic stroke; in $2018-81.8 \%$ in women in general and $91.1 \%$ with ischemic stroke) compared to VCCHEMS (2017 - $75.5 \%$ in men in general and $84.4 \%$ with ischemic stroke; $2018-88.2 \%$ in women in general and $95.7 \%$ with ischemic stroke).

In VRCPNH, during the study period, the percentage of men with hemorrhagic stroke who received statins decreased significantly $(\mathrm{p}<0.05-0.01)(2017-24.3 \% ; 2018-8.9 \% ; 2019-0 \%)$.

In VCCHEMS, the percentage of patients receiving statins in 2018 was significantly $(\mathrm{p}<0.05$ 0.001) higher than in 2017 and 2019 (in $2017-75.5 \%$ in men in general, $84.4 \%$ with ischemic stroke; $76.1 \%$ in women in general, $84.1 \%$ with ischemic stroke; in $2018-82.9 \%$ in men in general, $92.8 \%$ with ischemic stroke; $88.2 \%$ in women in general, $95.7 \%$ with ischemic stroke; in $2019-81.6 \%$ in women in general and $86.3 \%$ with ischemic stroke). During the study period, the percentage of women with hemorrhagic stroke who received statins decreased significantly $(\mathrm{p}<0.05-0.01)$ (in 2017 $15.4 \%$; in $2018-0 \%$ ).

When comparing the percentage of patients who received antihypertensive drugs, VRCPNH in 2017 found a significantly $(\mathrm{p}<0.05)$ higher, and in 2018-2019 significantly $(\mathrm{p}<0.05-0.001)$ its smaller 
value (2017 - 76.0\% in men with hemorrhagic stroke; $89.5 \%$ in women in general and $91.3 \%$ with ischemic stroke; in $2018-83.7 \%$ in men in general, $85.0 \%$ with ischemic stroke and $92.9 \%$ with hemorrhagic stroke; $81.8 \%$ in women in general and $75.6 \%$ in ischemic stroke; in $2019-88.7 \%$ in men with ischemic stroke; $78.9 \%$ in women in general and $79.6 \%$ in ischemic stroke) compared to VCCHEMS (2017 - 64.3\% in men with hemorrhagic stroke; $82.1 \%$ in women in general and $83.8 \%$ with ischemic stroke; in $2018-93.2 \%$ in men in general, $93.1 \%$ with ischemic stroke and $94.1 \%$ with hemorrhagic stroke; $94.1 \%$ in women in general and $96.1 \%$ with ischemic stroke; in 2019 $94.4 \%$ in men with ischemic stroke; $92.6 \%$ in women in general and $92.2 \%$ with ischemic stroke).

In VRCPNH, the percentage of men who received antihypertensive drugs increased significantly over time ( $\mathrm{p}<0.05)$, and in women - on the contrary, significantly decreased $(\mathrm{p}<0.01)$ (in $2017-83.7 \%$ for men in general; $89.5 \%$ for women in general and $91.3 \%$ with ischemic stroke; in $2018-83.7 \%$ in men in general and $75.6 \%$ with hemorrhagic stroke; in $2019-89.5 \%$ in men in general and $94.9 \%$ with hemorrhagic stroke; $78.9 \%$ in women in general and $79.6 \%$ with ischemic stroke).

In VCCHEMS, the percentage of patients receiving antihypertensive drugs increased significantly over time $(\mathrm{p}<0.05-0.001)(2017-78.9 \%$ in men in general, $81.2 \%$ in ischemic stroke and $64.3 \%$ in hemorrhagic stroke; $82.1 \%$ in women in general, $83.8 \%$ with ischemic stroke and $69.2 \%$ with hemorrhagic stroke; in $2018-93.2 \%$ in men in general, $93.1 \%$ with ischemic stroke and $94.1 \%$ with hemorrhagic stroke; $94.1 \%$ in women in general, $96.1 \%$ with ischemic stroke and $70.8 \%$ with hemorrhagic stroke; in $2019-93.4 \%$ in men in general and $94.4 \%$ with ischemic stroke; $92.6 \%$ in women in general, $92.2 \%$ with ischemic stroke and $100 \%$ with hemorrhagic stroke).

In VRCPNH, the average door-to-needle time in 2018 was significantly $(\mathrm{p}<0.05-0.001)$ lower compared to 2017 and 2019 (2017 - 27.32 \pm 1.31 in men in general and with ischemic stroke; $27.59 \pm 1.23$ in women in general and with ischemic stroke; $2018-21.66 \pm 1.05$ in men in general and with ischemic stroke; $20.97 \pm 1.66$ in women in general and with ischemic stroke; in $2019-24.70 \pm 1.02$ in men in general and with ischemic stroke; $29.88 \pm 3.05$ in women in general and with ischemic stroke).

It is impossible to compare the average door-to-needle time between the two institutions and in the dynamics of VCCHEMS due to the lack of data in the medical histories of the latter (no recanalization procedure was performed).

In VRCPNH, the average duration of treatment in 2017 was significantly $(\mathrm{p}<0.05-0.01)$ shorter, and in 2018 and 2019 - significantly $(\mathrm{p}<0.05-0.001)$ longer $(2017-8.738 \pm 0.229$ in men in total, $8.350 \pm 0.226$ with ischemic stroke, $9.108 \pm 0.704$ with hemorrhagic stroke; $8.350 \pm 0.226$ in women in general and 8.232 \pm 0.241 with ischemic stroke; $2018-9.563 \pm 0.257$ in men in general, $9.451 \pm 0.283$ with ischemic stroke; $9.012 \pm 0.314$ in women in general and $9.033 \pm 0.342$ with ischemic stroke; in $2019-9.671 \pm 0.347$ in women in general and $9.556 \pm 0.347$ with ischemic stroke) compared with VCCHEMS (2017 - 9.521 \pm 0.162 in men in general, 9.304 \pm 0.162 with ischemic stroke, $11.05 \pm 0.59$ with hemorrhagic stroke; $9.371 \pm 0.225$ in women in general and $9.235 \pm 0.231$ with ischemic stroke; $2018-8.493 \pm 0.179$ in men in general, $8.150 \pm 0.169$ with ischemic stroke; $8.446 \pm 0.159$ in women in general and $8.355 \pm 0.153$ with ischemic stroke; $2019-8.344 \pm 0.178$ in women in general and $8.313 \pm 0.185$ with ischemic stroke).

In VRCPNH, the average duration of treatment in 2017 was significantly $(\mathrm{p}<0.05-0.001)$ shorter than in 2018 and 2019 (2017 - 8.738 \pm 0.229 in men in general, $8.350 \pm 0.226$ with ischemic stroke; 8.232 \pm 0.241 in women with ischemic stroke; $2018-9.563 \pm 0.257$ in men in general, $9.451 \pm 0.283$ with ischemic stroke; $9.012 \pm 0.314$ in women in general and $9.033 \pm 0.342$ with ischemic stroke; in $2019-9.391 \pm 0.229$ in men in general; $9.671 \pm 0.347$ in women in general and $9.556 \pm 0.347$ with ischemic stroke).

In VCCHEMS, the average duration of treatment also decreased significantly over time $(\mathrm{p}<0.05-$ $0.001)$ (2017 - 9.521 \pm 0.162 in men in general and 9.304 \pm 0.162 in ischemic stroke; $9.371 \pm 0.225$ in women in general and 9.235 \pm 0.231 with ischemic stroke; $2018-8.493 \pm 0.179$ in men in general, $8.150 \pm 0.169$ with ischemic stroke; $8.446 \pm 0.159$ in women in general and $8.355 \pm 0.153$ with ischemic stroke; $2019-8.344 \pm 0.178$ in women in general and $8.313 \pm 0.185$ with ischemic stroke).

There were no significant differences in the performance of surgical treatment of hematoma between medical institutions and in the dynamics of time.

The implementation of the program to combat ischemic stroke, which introduced the method of thrombolytic reperfusion therapy, has allowed in recent years to achieve significant success in the treatment and rehabilitation of patients $[11,12,13]$. The method is based on the concept of ischemic 
penumbra, which prevents or minimizes the development of irreversible damage to the substance of the brain $[14,15]$. However, the time parameter ("door-to-needle time") can be a problematic aspect of the success and efficiency of this procedure. This indicator, along with the duration of treatment, the fact of hospitalization for stroke, in the analysis of the hospital register allows us to judge the organization of care for stroke patients and its impact on the consequences of the disease.

Conclusions. Analysis of the dynamics of treatment duration for the period 2017-2019 shows its decrease in VCCHEMS and increase in VRCPNH. The rate of hospitalization in the stroke unit for both hospitals in 2019 compared to previous years has increased. A study of the duration of door-toneedle time in VRCPNH shows its increase in 2019 compared to 2017 and 2018. There is an increase in the percentage of patients prescribed antithrombolytic drugs with a high degree of evidence and safety (rivaroxaban and dabigatran). The percentage of patients taking antihypertensive drugs and statins has increased, which may indicate both adherence to uniform treatment protocols and the fact that the percentage of patients with hypercholesterolemia and hypertension is increasing over time.

\section{REFERENCES}

1. Зозуля, І. С., Зозуля, А. І., \& Волосовець, А. О. (2017). Актуально ли создание инсультных отделений (инсультных блоков-stroke unit) в системе предоставления специализированной медицинской помощи при сосудистых заболеваниях головного мозга. Медицина неотложных состояний, 8(87), 110-115.

2. Alberts, M. J., Latchaw, R. E., Selman, W. R., Shephard, T., Hadley, M. N., Brass, L. M., ... \& Croft, J. B. (2005). Recommendations for comprehensive stroke centers: a consensus statement from the Brain Attack Coalition. Stroke, 36(7), 1597-1616.

3. Зозуля, І. С., Зозуля, А. І., \& Волосовець, А. О. (2016). Створення інсультних центрів залишається проблемою№ 1 у боротьбі з мозковими інсультами. Медицина неотложных состояний, 6 (77), 11-16.

4. Fearon, P., Langhorne, P., \& Trialists, E. S. D. (2012). Services for reducing duration of hospital care for acute stroke patients. Cochrane database of systematic reviews, (9), 97.

5. Langhorne, P., Baylan, S., \& Trialists, E. S. D. (2017). Early supported discharge services for people with acute stroke. Cochrane Database of Systematic Reviews, (7), 501-506.

6. Зозуля, I. С., Зозуля, А. І., \& Волосовець, А. О. (2017). Деякі напрямки поліпшення надання медичної допомоги при мозковому інсульті. Украӥнський вісник психоневрологї, (25, вип. 1), 84-85.

7. Стаховская, Л. В., \& Котов, С. В. (2014). Инсульт: Руководство для врачей. М.: ООО Издательство «Медицинское информационное агентство».

8. Суслина, 3. А., Гулевская, Т. С., Максимова, М. Ю., \& Моргунов, В. А. (2016). Нарушения мозгового кровообращения: диагностика, лечение, профилактика. М.: МЕДпресс-информ.

9. Хамидова, 3. М., Масюткина, Л. Н., \& Абрамычева, Н. Ю. (2012). Оптимизация подходов к профилактике ишемических инсультов с использованием возможностей фармакогенетики. Нервные болезни, (2), 21-26.

10. Дельва, М.Ю. (2013). Вплив аторвастатину на клініко-функціональні показники при ішемічних лакунарних інсультах у осіб з абдомінальним ожирінням. Мир медищины и биологии, 9 (2-2, 38), 116-119.

11. Домашенко, М. А., Гафарова, М. Э., \& Максимова, М. Ю. (2016). Персонификация подходов к тромболитической терапии ишемического инсульта: предикторы эффективности. Нервные болезни, (3), 34-38.

12. Бокерия, Л. А., Покровский, А. В., Сокуренко, Г. Ю., Самородская, И. В., Абугов, С. А., \& Алекян, Б. Г. (2013). Национальные рекомендации по ведению паџиентов с заболеваниями брахиоцефальных артерий. Российский согласительный документ.

13. Furie, K. L., Kasner, S. E., Adams, R. J., Albers, G. W., Bush, R. L., Fagan, S. C., ... \& Mitchell, P. H. (2011). Guidelines for the prevention of stroke in patients with stroke or transient ischemic attack: a guideline for healthcare professionals from the American Heart Association/American Stroke Association. Stroke, 42(1), 227-276.

14. Домашенко, М. А., Гафарова, М. Э., \& Максимова, М. Ю. (2016). Персонификация подходов к тромболитической терапии ишемического инсульта: предикторы эффективности. Нервные болезни, (3), 34-38.

15. Домашенко, М. А., Максимова, М. Ю., Лоскутников, М. А., Никонов, А. А., Брюхов, В. В., Суслин, А. С., .. \& Коновалов, Р.Н. (2015). Механизмы реперфузии при внутривенной тромболитической терапии у пациентов с ишемическим инсультом. Нервные болезни, (3), 41-44. 